\title{
The Introduction of Bromocresol Purple for the Determination of Serum Albumin on SMAC and ACA, and the Standardization Procedure
}

\author{
By H. A. Assink ${ }^{1}$ ), B. G. Blijenberg, G. J. M. Boerma and B. Leijnse \\ Department of Clinical Chemistry, University Hospital Rotterdam-Dijkzigt \\ and Department of Chemical Pathology, Erasmus University, Rotterdam, The Netherlands
}

(Received February 15/July 4, 1984)

\begin{abstract}
Summary: The bromocresol purple methods for the determination of serum albumin on the Technicon SMAC and the DuPont ACA systems were evaluated and compared with the corresponding bromocresol green methods, a radial immunodiffusion (RID) and an electrophoresis technique. The linearity and precision of the dye binding methods were comparable. The bromocresol purple methods were more influenced by lipaemia and to a lesser extent by high bilirubin concentrations. The specificity of the bromocresol purple methods was superior to that of the bromocresol green methods and showed excellent correlations with the radial immunodiffusion method: bromocresol purple: $\mathrm{SMAC}=1.03$ (RID) +0.32 ; bromocresol purple: $\mathrm{ACA}=1.00$ (RID) +1.27 . The bromocresol purple methods intercorrelated better than the bromocresol green methods.

Freeze-dried sera can be used for albumin standardization. Analysis of the albumin fractions of freeze-dried and liquid sera by high-performance liquid chromatography (HPLC) did not reveal significant differences in albumin polymerization. Purified albumin reacted, irrespective of the degree of polymerization, very differently in the dye-binding methods. The bromocresol purple methods showed an overestimation of purified albumin, the bromocresol green methods an underestimation. The reason for these differences is unclear. Non-human albumin reacted poorly with bromocresol purple in contrast with bromocresol green.
\end{abstract}

Die Einführung von Bromkresolpurpur für die Bestimmung von Albumin im Serum mit dem SMAC und dem ACA sowie das Standardisierungsverfahren

Zusammenfassung: Die Bromkresolpurpur-Methode zur Bestimmung von Albumin im Serum mit dem Technicon SMAC and dem Dupont ACA wurde kritisch untersucht und mit den entsprechenden BromkresolgrünMethoden, dẹr radialen Immundiffusion und einem elektrophoretischen Verfahren verglichen. Linearität und Präzision der Farbstoffbindungs-Methoden waren vergleichbar. Die Bromkresolpurpur-Methoden wurden durch Lipämie stärker, durch hohe Bilirubinkonzentrationen in geringerem Umfang beeinflußt. Die Spezifität der Bromkresolpurpur-Methoden war der der Bromkresolgrün-Methoden überlegen. Die Bromkresolpurpur-Methode (y) zeigte eine sehr gute Korrelation mit der radialen Immundiffusion ( $x$ ): für den SMAC $y=$ $\ddot{1}, 03 x+0,32$, für den ACA $y=1,00 x+1,27$. Die Bromkresolpurpur-Methoden mit dem SMAC und dem ACA korrelierten untereinander besser als die entsprechenden Bromkresolgrün-Methoden.

Für die Standardisierung der Albuminbestimmung können lyophilisierte Seren benutzt werden. Die Analyse der Albuminfraktionen lyophilisierter und flüssiger Seren mit Hochleistungsflüssigkeitschromatographie ergab keine signifikanten Differenzen bezüglich der Polymerisation von Albumin. Gereinigtes Albumin reagierte ungeachtet des Polymerisationsgrades in den Farbstoffbindungs-Methoden sehr unterschiedlich: die Bromkresolpurpur-Methoden ergaben für gereinigtes Albumin einen höheren, die Bromkresolgrün-Methoden einen geringeren Wert als den Zielwert. Der Grund für diese Unterschiede ist unklar. Albumin anderer Species reagierte verglichen mit Bromkresolgrün schlecht mit Bromkresolpurpur.

') Present address: Dept. of Clinical Chemistry, Wilhelmina Ziekenhuis, Zuidersingel 1, NL-9400 RA Assen, The Netherlands. 


\section{Introduction}

For the determination of serum albumin the bromocresol green dye binding method is very popular. However this method is liable to interference from $\alpha$ - and $\beta$-globulins (1). Modifications of the bromocresol green reagent and the reaction conditions have never led to a successful elimination of the interference (2-4). The introduction of a related dye, bromocresol purple (5) seemed promising and the specificity has been confirmed by many authors (610). In our laboratory, the bromocresol green methods on the Technicon SMAC and DuPont ACA systems have frequently given results that contradict those from electrophoresis and radial immunodiffusion (RID) techniques. We investigated whether the introduction of bromocresol purple on SMAC and ACA improved the specificity and the comparability with the other techniques.

A problem of albumin determinations in general and of the bromocresol purple method in particular is the standardization. Non-human albumin reacts poorly with bromocresol purple and can not be used for calibration $(6,11)$. Purified human albumin preparations contain aggregates $(12,13)$ that influence the immunochemical and bromocresol green methods $(13,14)$. This influence is not always taken into account in standardization procedures, and comparisons of methods $(15-17)$.

However there is no consensus on the use of freezedried sera in the calibration of albumin assays. The IFCC rejects freeze-dried sera, because of the induction of albumin polymers; the Expert Panel on Proteins therefore proposed and made a liquid serum standard 'IFCC 74/1' (13). The W.H.O. neglected this phenomenon in native sera and made a freezedried serum standard 'W.H.O. International Reference Preparation of Six Human Serum Proteins' (18). Also, some manufacturers provide freeze-dried human sera for calibration (Technicon, DuPont). We purchased the above mentioned sera, isolated their albumin fractions by affinity chromatography and analysed these by high-performance liquid chromatography (HPLC) to see which standardization method is correct.

\section{Materials and Methods}

Preparation of a human serum standard

Four units of fresh human donor blood were clotted, the serum separated and mixed thoroughly. After being kept overnight at $4{ }^{\circ} \mathrm{C}$ the serum was filtered and sodium azide was added to a final concentration of $1 \mathrm{~g} / \mathrm{l}$. Ampoules of serum containing about $1 \mathrm{ml}$ were stored at $-70^{\circ} \mathrm{C}$ until analysis.

\section{Standardization}

The serum was standardized, using the radial immunodiffusion. technique (RID), against two international serum standards: the IFCC 74/1 and the W.H.O. International Reference Preparation of Six Human Serum Proteins (W.H.O. serum). Serial dilutions of all sera were analysed in triplicate during; three consecutive days. The results were calculated as described by Reimer et al. (18). The donor serum is used as a laboratory standard for all our albumin determinations except the electrophoresis.

\section{Isolation of serum albumin}

Albumin was isolated from sera by affinity chromatography on Reactive Blue 2-Sepharose CL-6B (Sigma, R 8752), based on the method of Travis et al. (19). Serum $(300 \mu \mathrm{l})$ was applied to a $5 \mathrm{ml}$ gel column equilibrated with $0.05 \mathrm{~mol} / 1 \mathrm{Tris}-\mathrm{HCl}, 0.1 \mathrm{~mol} / \mathrm{l} \mathrm{NaCl}$, $\mathrm{pH} 8.0$. The eluate was collected until the absorbance at $280 \mathrm{~nm}$ was $<0.010$ and concentrated by ultrafiltration on Amicon B-15 filters. The albumin was eluted with $0.05 \mathrm{~mol} / \mathrm{l}$ Tris- $\mathrm{HCl}, 0.1$ $\mathrm{mol} / / \mathrm{NaCl}, 0.05 \mathrm{~mol} / / \mathrm{KSCN}, \mathrm{pH}$ 8.0. To prevent polymerization the eluate was immediately dialysed against the chromatography buffer until all KSCN was removed. For analysis by our HPLC method the samples were not concentrated.

\section{HPLC}

Chromatographic analyses were performed with an LKB HPLC system consisting of an LKB 2150 HPLC-pump, an Ultro-Pac TSK G $3000 \mathrm{SW}(7.5 \times 600 \mathrm{~mm})$ column and a LKB 2138 Uvicord $S$ detector set at $206 \mathrm{~nm}$. The chromatography buffer was 0.1 mol/ sodium phosphate; $0.1 \mathrm{~mol} / / \mathrm{NaCl}, \mathrm{pH} 6.8$. The flow rate was $1.00 \mathrm{ml} / \mathrm{min}$. Sample volume was $20 \mu \mathrm{l}$, containing about $20 \mu \mathrm{g}$ of protein. Since sodium azide caused a high background absorbance, it was omitted.

\section{Albumin assays}

A bromocresol green method was performed on the Technicon SMAC system (method No. SG4-(0030 FH9), with Technicon reagents. A bromocresol purple method on the SMAC used the same channel and flow diagram. The carriy-ồver correction was checked and set at $3 \%$. The bromocresol purple reagent for the SMAC was prepared according to Pinnell \& Northam (6) with the modification of Haythorn \& Sheehan (20). The reaction conditions are shown in table 1.

Tab. 1. Reaction conditions of the dye-binding methods.

\begin{tabular}{lclll}
\hline & $\begin{array}{l}\text { SMAC } \\
\text { Bromo- } \\
\text { cresol } \\
\text { purple }\end{array}$ & $\begin{array}{l}\text { Bromo- } \\
\text { cresol } \\
\text { green }\end{array}$ & $\begin{array}{l}\text { ACA } \\
\text { Bromo- } \\
\text { cresol } \\
\text { purple }\end{array}$ & $\begin{array}{l}\text { Bromo- } \\
\text { cresol } \\
\text { green }\end{array}$ \\
\hline & & & & \\
Buffer & Acetate & n.s. & Acetate & Acetate \\
Buffer conc. (mmol/l) & 75 & n.s. & 125 & 90 \\
Buffer pH & 5.2 & 4.2 & 4.9 & 4.2 \\
Dye conc. $(\mu \mathrm{mol} / \mathrm{l})$ & 80 & n.s. & 250 & 200 \\
Brij-35 conc. $(\mathrm{g} / \mathrm{l})$ & 0.25 & n.s. & n.s. & n.s. \\
Sample reagent ratio & $1 / 236$ & $1 / 236$ & $1 / 250$ & $1 / 250$ \\
Temperature $\left({ }^{\circ} \mathrm{C}\right)$ & $\mathrm{RT}$ & $\mathrm{RT}$ & 37 & 37 \\
Reaction time $(\mathrm{min})$ & 1.5 & 1.5 & 0.5 & 4.3 \\
Filter $(\mathrm{nm})$ & 600 & 630 & $600 / 540$ & $600 / 540$ \\
& & & & \\
\hline
\end{tabular}

n.s.: not specified.

RT: room temperature: 
Bromocresol green and bromocresol purple methods were also performed on a DuPont ACA III analyser, using DuPont reagent packs and according to the manufacturers instructions (tab. 1). Serum electrophoresis was performed on cellulose acetate with Ponccau-S staining.

Total protein was determined by the biuret method on the SMAC (21). The radial immunodiffusion technique was carried out with P'artigen ${ }^{\otimes}$ plates from Behringwerke.

The statistical evaluation of the method comparisons was performed by the procedure of Deming (21).

\section{Control sera}

Human and non-human control scra were purchased from different manufacturers. Versatol (General Diagnostics), was 1 year out of date.

\section{Results}

\section{Serum calibration}

The calibration of our donor serum against the W.H.O. and IFCC standard sera resulted in a concentration of $40.5 \pm 0.3 \mathrm{~g} / \mathrm{l}(102.2 \pm 0.9 \mathrm{IU} / \mathrm{ml})$. The W.H.O. value was only stated as $\mathrm{IU} / \mathrm{ml}$ and the IFCC value only as $\mathrm{g} / \mathrm{l}$. We found that $1 \mathrm{mg}$ of albumin corresponds to $2.53 \pm 0.03 \mathrm{IU}$.

\section{Detection of albumin polymers}

To detect any possible presence of albumin polymers in different sera the albumin fractions were isolated by affinity chromatography on Reactive Blue 2-Sepharose CL-6B. The efficiency of this separation method was checked with purified human albumin (Hoechst-ORHA), containing $11 \%$ dimers and $2 \%$ polymers, and with an albumin monomer fraction, isolated from the albumin preparation by Sephadex G-200 chromatography. The recovery of the affinity chromatography was more than $96 \%$ without detectable relative loss of polymers or induction of polymers. The isolated albumin fractions were also assessed by immunoelectrophoresis. Only albumin and small traces of prealbumin and $\alpha$-globulins could be seen after concentration. The HPLC patterns of some isolated albumin fractions can be seen in figure 1. In fresh serum, 'old' serum $\left(1 / 2\right.$ year $\left.-20^{\circ} \mathrm{C}\right)$ and freeze-dried serum we found $0.5-1.5 \%$ albumin dimers (tab. 3). These differences in polymer content were not significant. In the Albumin Calibrator of DuPont the dimer percentage was 2.5 and in a 1 year outdated lot of Versatol (General Diagnostics) control serum, about $4.5 \%$ dimers and $0.5 \%$ polymers were detected.

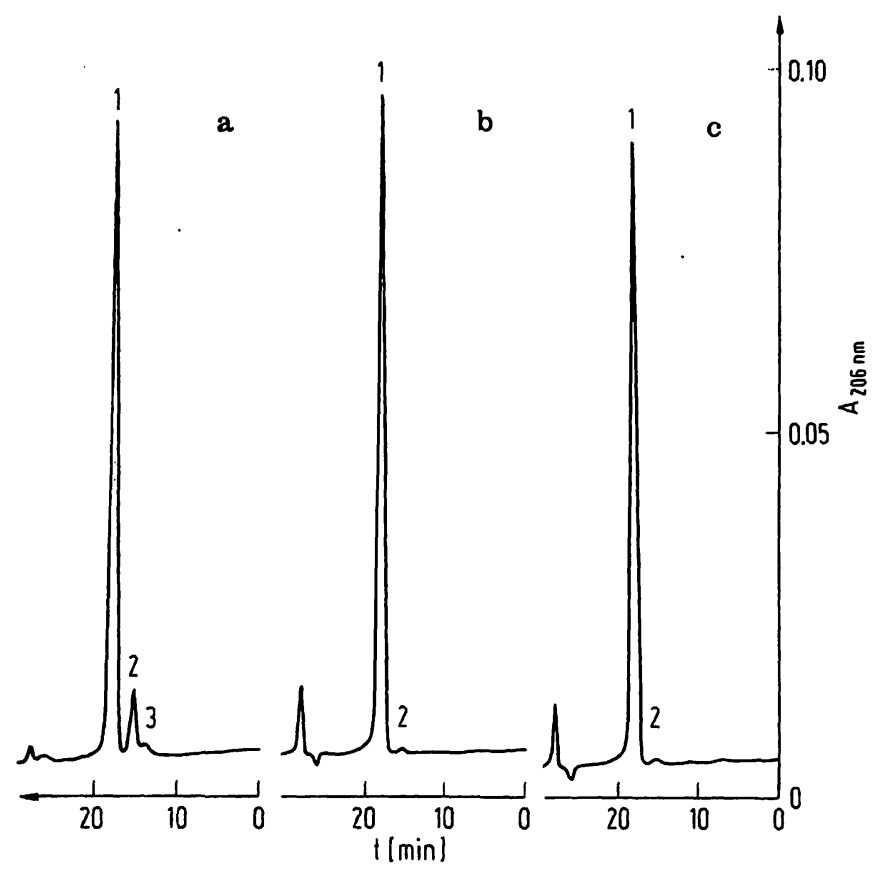

Fig. 1. Chromatogram of

a) Hoechst-ORHA purified human albumin,

b) Albumin fraction of the IFCC standard serum, c) Albumin fraction of the W.H.O. standard serum: 1 = Albumin monomer, 2 = Albumin dimer, 3 = Albumin trimer.

Analytical performance of the bromocresol purple methods

We analysed the performance of the bromocresol purple methods on the ACA and SMAC in comparison with the bromocresol green methods. All the assays showed good linearity up to an albumin concentration of $70 \mathrm{~g} / \mathrm{l}$. Precision studies did not reveal great discrepancies. The between-run coefficients of variation for the various methods were:

bromocresol purple, SMAC: $1.1-1.7 \%$, bromocresol green, SMAC: $1.1-2.2 \%$, bromocresol purple, ACA: $1.6-2.3 \%$, bromocresol green, ACA: $1.2-2.6 \%$. covering an albumin concentration range of $22-48$ $\mathrm{g} / \mathrm{l}$.

The results of the interference experiments are shown in table 2. Sodium salicylate and haemoglobin had negligible influence on the results. High bilirubin concentrations influenced the bromocresol purple SMAC method to a certain extent, while triglycerides showed a marked influence. In the bromocresol purple methods this phenomenon was more pronounced than in the bromocresol green methods. The specificity was studied by analysing 
Tab. 2. Influence of possible interfering substances.

\begin{tabular}{|c|c|c|c|c|c|c|}
\hline \multirow[t]{2}{*}{$\begin{array}{l}\text { Interfering } \\
\text { substance }\end{array}$} & \multirow{2}{*}{\multicolumn{2}{|c|}{ Concentration }} & \multicolumn{4}{|c|}{$\begin{array}{l}\text { Interference } \\
\text { (difference in albumin, } g / l \text { ) }\end{array}$} \\
\hline & & & $\begin{array}{l}\text { SMAC } \\
\text { Bro- } \\
\text { mo- } \\
\text { cresol } \\
\text { purple }\end{array}$ & $\begin{array}{l}\text { Bro- } \\
\text { mo- } \\
\text { cresol } \\
\text { green }\end{array}$ & $\begin{array}{l}\text { ACA } \\
\text { Bro- } \\
\text { mo- } \\
\text { cresol } \\
\text { purple }\end{array}$ & $\begin{array}{l}\text { Bro- } \\
\text { mo- } \\
\text { cresol } \\
\text { green }\end{array}$ \\
\hline Bilirubin & 100 & $\mu \mathrm{mol} / \mathrm{l}$ & 0 & 0 & 0 & 0 \\
\hline Bilirubin & 225 & $\mu \mathrm{mol} / \mathrm{l}$ & -1 & 0 & 0 & 0 \\
\hline Bilirubin & 500 & $\mu \mathrm{mol} / \mathrm{l}$ & -2 & 0 & 0 & 0 \\
\hline Bilirubin & 1000 & $\mu \mathrm{mol} / \mathrm{l}$ & -1 & 0 & -1 & 0 \\
\hline Na-salicylate & 150 & $\mathrm{mg} / \mathrm{l}$ & 0 & 0 & 0 & 0 \\
\hline Na-salicylate & 300 & $\mathrm{mg} / \mathrm{l}$ & 0 & 0 & 0 & 0 \\
\hline Haemoglobin & 0.0 & $5 \mathrm{mmol} / \mathrm{l}$ & 0 & 0 & 0 & 0 \\
\hline Haemoglobin & 0.1 & $0 \mathrm{mmol} / \mathrm{l}$ & 0 & 0 & 0 & 0 \\
\hline Haemoglobin & & $0 \mathrm{mmol} / \mathrm{l}$ & 0 & +1 & -1 & 0 \\
\hline Triglycerides & 2.2 & $\mathrm{mmol} / \mathrm{l}$ & +6 & +2 & -1 & 0 \\
\hline Triglycerides & 4.4 & $\mathrm{mmol} / \mathrm{l}$ & +10 & +6 & -3 & 0 \\
\hline Triglycerides & 8.7 & $\mathrm{mmol} / \mathrm{l}$ & +17 & +12 & -5 & 0 \\
\hline
\end{tabular}

the albumin-free protein fractions from the affinity chromatography. Because of the small quantities of material available we only employed the ACA methods (tab. 3). The bromocresol green method showed the greatest interference from other proteins, although the bromocresol purple ACA method was not completely free from such interference. Human $\gamma$-globulins: also gave a response of about $10 \%$ with bromocresol green (tab. 3).

In the recovery experiments 10 sera were spiked with purified human albumin (Hoechst-ORHA). The added albumin was in most cases recovered badly:

bromocresol purple, SMAC: $105 \pm 2 \%$, bromocresol green, SMAC: $92 \pm 3 \%$, bromocresol purple, ACA: $96 \pm 5 \%$, bromocresol green, ACA: $\quad 81 \pm 2 \%$.
Tab. 3. Albumin concentration in albumin-free scrum fractions prepared by affinity chromatography.

\begin{tabular}{|c|c|c|c|c|c|}
\hline \multirow[t]{2}{*}{ Origin of fraction } & \multirow{2}{*}{$\begin{array}{l}\text { Ratio mono- } \\
\text { mer/dimer/ } \\
\text { polymer }\end{array}$} & \multirow{2}{*}{$\begin{array}{l}\text { Total } \\
\text { protein }\end{array}$} & \multicolumn{2}{|c|}{ Albumin $(g / 1)$} & \multirow[b]{2}{*}{ RID } \\
\hline & & & $\begin{array}{l}\text { Bro- } \\
\text { mo- } \\
\text { cresol } \\
\text { purple, } \\
\text { ACA }\end{array}$ & $\begin{array}{l}\text { Bro- } \\
\text { mo- } \\
\text { cresol } \\
\text { green, } \\
\text { ACA }\end{array}$ & \\
\hline Own calibrator & $99.0 / 1.0 / 0$ & 26.4 & 1.5 & 7.5 & 0.1 \\
\hline IFCC serum & $98.5 / 1.5 / 0$ & 24.9 & 1.7 & 6.9 & 0.1 \\
\hline W.H.O. serum & $98.5 / 1.5 / 0$ & 19.7 & 2.0 & 4.5 & 0.0 \\
\hline $\begin{array}{l}\text { 'Old' serum } \\
\left(1 / 2 \text { year }-20^{\circ} \mathrm{C}\right)\end{array}$ & $98.5 / 1.5 / 0$ & 30.8 & 2.0 & 8.0 & 0.1 \\
\hline Fresh serum & $99.5 / 0.5 / 0$ & 29.9 & 1.4 & 7.4 & 0.0 \\
\hline $\begin{array}{l}\text { Purified human } \\
\gamma \text {-globulin fraction } \\
\text { (Hoechst) }\end{array}$ & & 110 & 0.5 & 10.3 & 1.1 \\
\hline
\end{tabular}

This seemed to be caused by different reactivities to purified albumin. We therefore measured different albumin preparations by the dye binding methods and compared the results with those from radial immunodiffusion and the direct $\mathrm{A}_{280 \mathrm{~nm}}$ measurement (tab. 4). The results agreed with the recovery experiments. The bromocresol purple methods gave higher values for albumin compared with the radial immunodiffusion and the $A_{280 \mathrm{~nm}}$ measurements; the bromocresol green methods gave lower values for albumin. These deviations were not caused by the albumin polymerization.

\section{Patient sera comparison}

Split sample comparisons were made between the dye binding methods and the radial immunodiffusion technique (figs. 2-5). The bromocresol purple methods showed good agreement with the radial immunodiffusion method. The bromocresol purple methods mutually coincided somewhat better than

Tab. 4. Mean albumin concentration in different albumin preparations.

\begin{tabular}{|c|c|c|c|c|c|c|c|}
\hline \multirow[t]{2}{*}{ Preparation } & \multirow{2}{*}{$\begin{array}{l}\text { Ratio mono- } \\
\text { mer/dimer/ } \\
\text { trimer }\end{array}$} & \multicolumn{6}{|c|}{$\operatorname{Albumin}(\mathrm{g} / \mathrm{l}) \pm \mathrm{SD}^{*}$} \\
\hline & & $\begin{array}{l}\text { SMAC } \\
\text { Bromocresol } \\
\text { purple }\end{array}$ & $\begin{array}{l}\text { Bromocresol } \\
\text { green }\end{array}$ & $\begin{array}{l}\text { ACA } \\
\text { Bromocresol } \\
\text { purple }\end{array}$ & $\begin{array}{l}\text { Bromocresol } \\
\text { green }\end{array}$ & RID & $\mathrm{A}_{280 \mathrm{~nm}}{ }^{* *}$ \\
\hline Hoechst-ORHA & $100 / 0 / 0$ & $37.0 \pm 0.5$ & $32.0 \pm 0.5$ & $36.7 \pm 0.6$ & $29.6 \pm 0.6$ & $33.0 \pm 0.5$ & $34.0 \pm 0.1$ \\
\hline Miles-Pentex & $98.5 / 1.5 / 0$ & - & - & $38.2 \pm 0.2$ & $30.0 \pm 0.4$ & $35.8 \pm 0.4$ & $33.2 \pm 0.1$ \\
\hline Hoechst-ORHA & $87 / 11 / 2$ & $48.0 \pm 0.5$ & $42.0 \pm 0.5$ & $47.1 \pm 0.6$ & $38.0 \pm 0.7$ & $43.8 \pm 0.6$ & $43.2 \pm 0.1$ \\
\hline
\end{tabular}


the bromocresol green methods. The regression parameters were:

bromocresol purple: $\mathrm{ACA}=0.96 \mathrm{SMAC}+1.22, \mathrm{~s}_{\mathrm{yx}}$ $=0.854, \mathrm{n}=95$ and

bromocresol green: $\mathrm{ACA}=0.91 \mathrm{SMAC},+2.48, \mathrm{~s}_{\mathrm{yx}}$ $=1.020, \mathrm{n}=95$.

Sera from patients with various clinical conditions were also analysed with the various methods (tab. 5). Electrophoresis showed high values. In extremely ic-

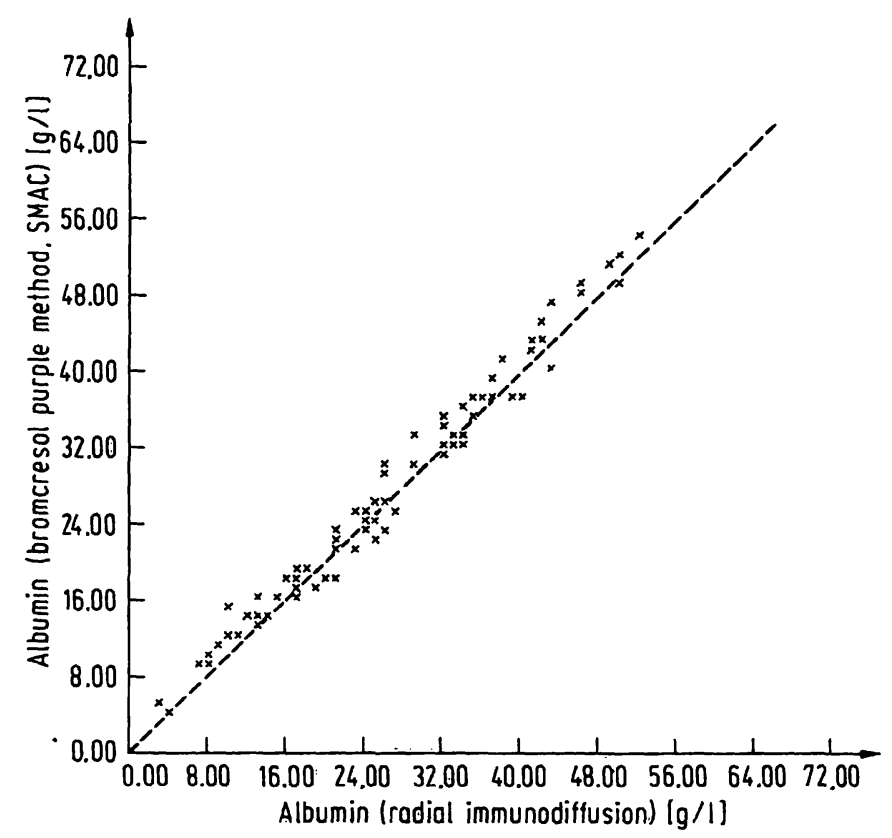

Fig. 2. Sample comparison of RID with bromocresol purple, SMAC. Regression parameters: slope $=1.03 \pm 0.02$, intercept $=0.32 \pm 0.47, \mathrm{n}=86, \overline{\mathrm{x}}=25.6, \overline{\mathrm{y}}=26.5, \mathrm{~s}_{\mathrm{yx}}=$ 1.82. Dotted line: $y=x$.

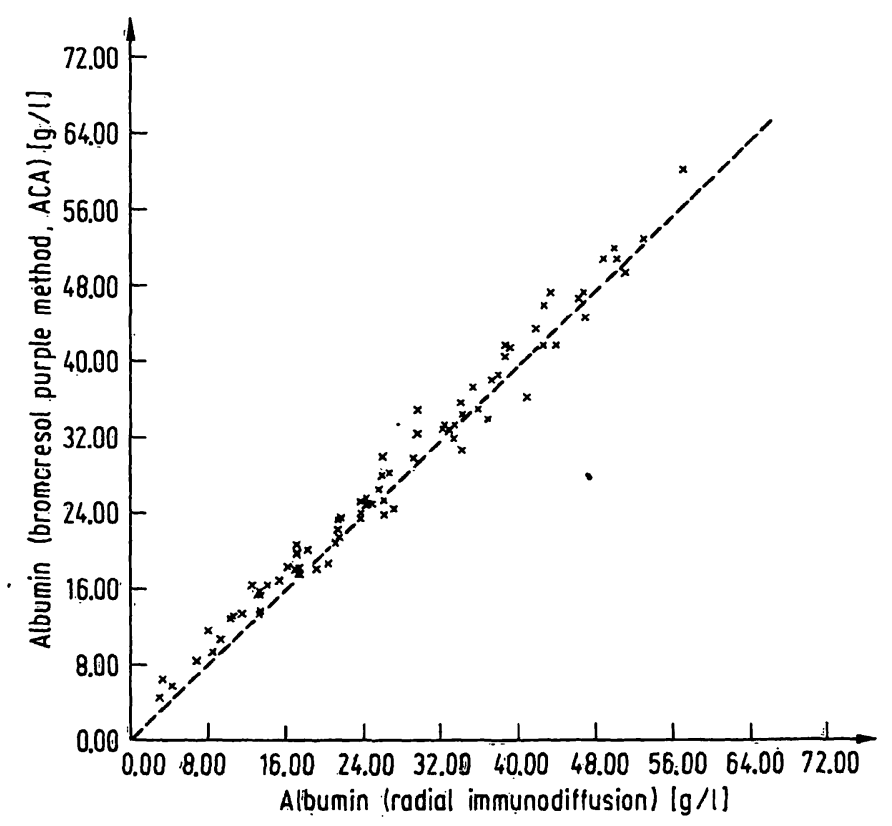

Fig. 4. Sample comparison of RID with bromocresol purple, ACA. Regression parameters: slope $=1.00 \pm 0.01$, intercept $=1.27 \pm 0.42, n=86, \bar{x}=26.0, \bar{y}=27.1, s_{y x}=$ 1.45. Dotted line: $y=x$. teric sera, the bromocresol purple SMAC method gave values that were about $2 \mathrm{~g} / \mathrm{l}$ lower than those obtained by radial immunodiffusion, as shown by the interference study (tab. 2). The other results were in agreement with the sample comparisons (figs. 2-5). In some sera with low albumin concentrations the bromocresol green methods corresponded quite well with the radial immunodiffusion method (figs. 3, 5). Most of these sera also had lowered $\beta$ - and $\gamma$-globulin fractions.

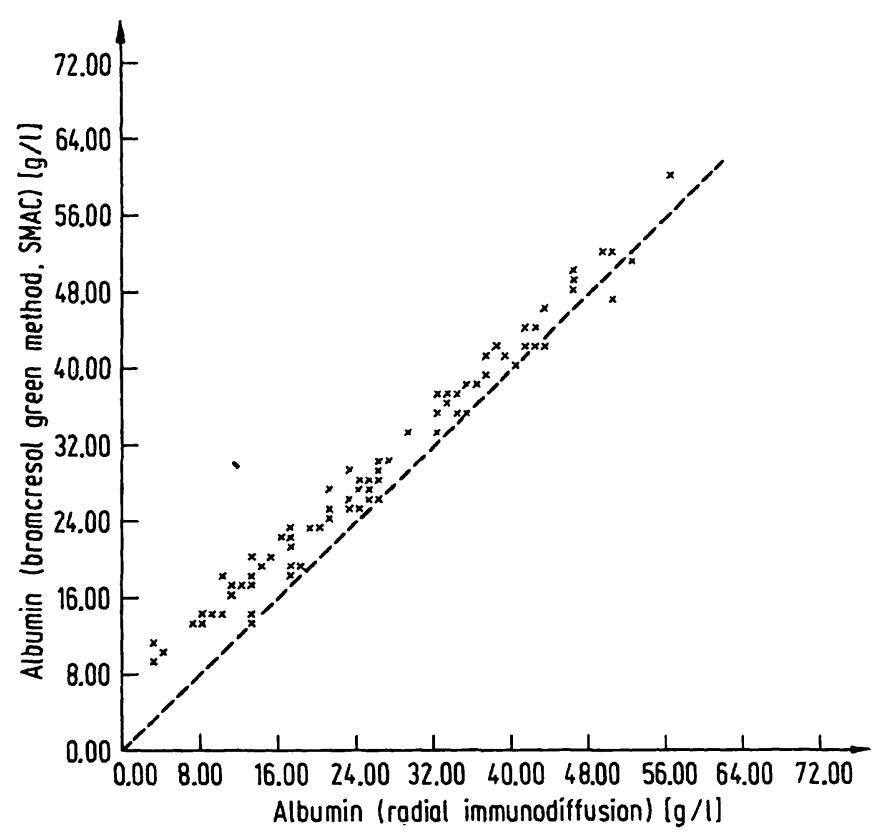

Fig. 3. Sample comparison of RID with bromocresol green, SMAC. Regression parameters: slope $=0.92 \pm 0.02$, intercept $=5.36 \pm 0.43, n=86, \bar{x}=25.6, \bar{y}=28.8, s_{y x}=$ 1.71. Dotted line: $y=x$.

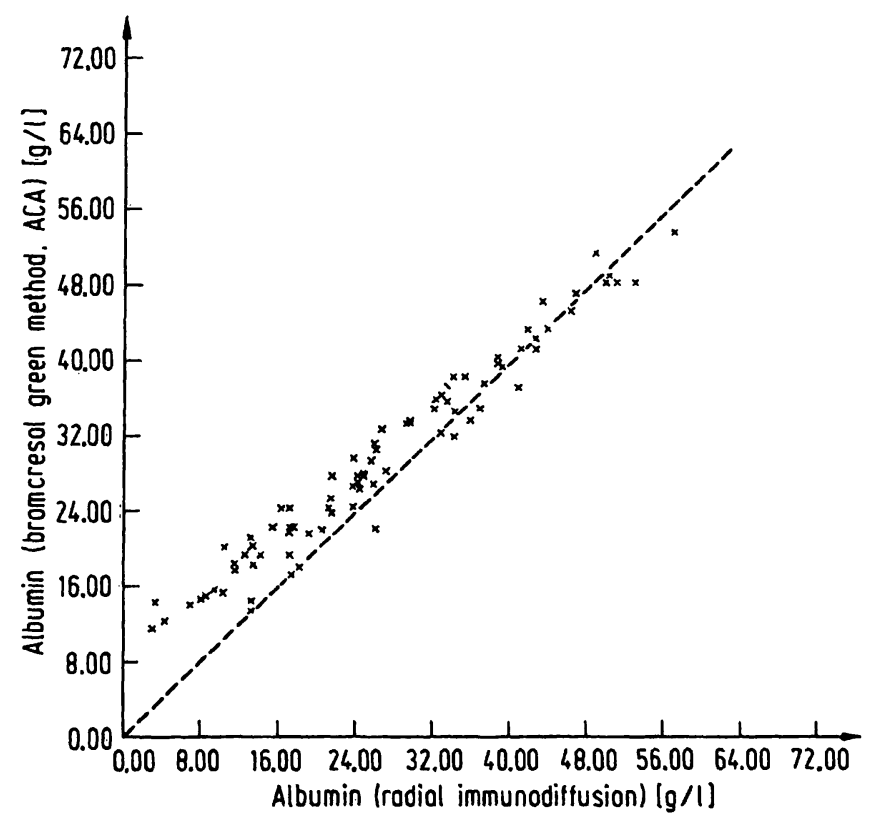

Fig. 5. Sample comparison of RID with bromocresol green, ACA. Regression parameters: slope $=0.84 \pm 0.02$, intercept $=7.19 \pm 0.60, n=84, \bar{x}=26.1, \bar{y}=29.1, s_{j x}=$ 3.29. Dotted line: $y=x$. 
Tab. 5. Mean albunin concentration in various clinical conditions.

\begin{tabular}{lll}
\hline Clinical condition $N$ & Albumin (g/l) & \\
& SMAC ACA & Elec- RID \\
& Bro- Bro- Bro- Bro- tro- \\
mo- mo- mo- mo- pho- & cresol cresol cresol cresol resis \\
purple green purple green
\end{tabular}

$\begin{array}{llllllll}\text { Acute phase } & 8 & 14.6 & 19.4 & 15.5 & 21.2 & 19.5 & 13.1 \\ \text { Paraproteinaemia } & 6 & 27.2 & 29.7 & 26.9 & 29.7 & 36.3 & 26.1 \\ \text { Liver disease } & 8 & 30.9 & 32.0 & 30.7 & 31.7 & 38.3 & 29.6 \\ \text { Haemodialysis* } & 9 & 32.9 & 35.1 & 32.9 & 33.7 & 43.0 & 33.2 \\ \text { Icterus** } & 9 & 20.1 & 25.0 & 21.5 & 23.8 & 30.3 & 22.0\end{array}$

*: mean urea concentration: $32 \mathrm{mmol} / \mathrm{l}$; mean creatinine concentration: $14(0) \mu \mathrm{mol} / \mathrm{l}$.

**: mean bilirubin concentration: $432 \mu \mathrm{mol} / \mathrm{l}$.

\section{Calibration sera and quality control sera}

Different calibration sera and quality control sera were analysed in 3 to 4 different runs (tab. 6). The results of the human control sera were comparable with those of the patient sera. Analyses of the nonhuman control sera showed marked differences between the bromocresol purple and bromocresol green methods, and different methods using the same dye also gave divergent results. Horse serum reacted quite differently from bovine and rabbit serum. Comparing the calibration sera, the assigned value of the human calibration serum from Behringwerke corresponded well with the IFCC calibration in the radial immunodiffusion assay. The assigned values of the DuPont and Technicon calibration sera were too high.

Tab. 6. Mean albumin concentration in control sera ( 19 commercial products) and calibration sera.

\begin{tabular}{llllll}
\hline Origin $\quad \mathrm{N}$ & \multicolumn{2}{l}{ Albumin $(\mathrm{g} / \mathrm{l})$} & & & \\
& SMAC & ACA & & RID & Stat- \\
& Bro- & Bro- & Bro- & Bro- & ed \\
& mo- & mo- & mo- & mo- & value \\
& cresol cresol & cresol & cresol & \\
& purple green & purple & grcen & \\
& &
\end{tabular}

\begin{tabular}{|c|c|c|c|c|c|c|c|}
\hline \multicolumn{8}{|c|}{ Control sera } \\
\hline Human & 8 & 33.1 & 35.8 & 35.0 & 34.1 & 32.8 & \\
\hline Bovine & 8 & 15.8 & 45.6 & 24.9 & 38.0 & - & \\
\hline Horse & 2 & 18.5 & 22.0 & 27.1 & 24.2 & - & \\
\hline Rabbit & 1 & 17.5 & 25.5 & 16.8 & 30.7 & - & \\
\hline \multicolumn{8}{|c|}{ Calibration sera } \\
\hline \multicolumn{2}{|c|}{$\begin{array}{l}\text { Standard human } \\
\text { serum (Hocchst) }\end{array}$} & - & - & 48.4 & 45.0 & 49.2 & 49.6 \\
\hline \multicolumn{2}{|c|}{$\begin{array}{l}\text { SMAC } \\
\text { Reference } 1 \\
\text { (Technicon) }\end{array}$} & 37.0 & 42.5 & 40.1 & 37.8 & 38.7 & 42 \\
\hline \multicolumn{2}{|c|}{$\begin{array}{l}\text { Alb calibrator } \\
\text { (DuPont) }\end{array}$} & 67.2 & 65.4 & 67.5 & 62.6 & 62.7 & 71.0 \\
\hline \multicolumn{2}{|c|}{ IFCC serum } & - & - & 40.5 & 39.6 & 40.3 & 40.3 \\
\hline \multicolumn{2}{|c|}{ W.H.O. serum } & - & - & 41.9 & 39.6 & $39: 5$ & 39.5 \\
\hline
\end{tabular}

\section{Discussion}

Our results indicate that the bromocresol purple methods evaluated for the SMAC and ACA systems are comparable with other bromocresol purple methods $(5,6,17)$. A recently published evaluation of the bromocresol purple ACA method (23) is in good agreement with our findings. On our instruments the precision was the same for bromocresol purple and bromocresol green methods, though bromocresol purple produces lower absorbances than bromocresol green (11) (55\% lower on the SMAC). The largest differences were caused by the interference from lipaemia. The bromocresol purple SMAC method was especially influenced by high triglyceride concentrations. Special treatment of high triglyceride sera would therefore be necessary before sample analysis. The interference from bilirubin, which caused an underestimation of albumin by the bromocresol purple SMAC method and, to a lesser extent, by the bromocresol purple ACA method, never exceeded $2 \mathrm{~g} / \mathrm{l}$ and was conjugation-independent. Purified unconjugated bilirubin showed the same interference as bilirubin in patient samples with a mean conjugation of $70 \%$ (tabs. 2,5 ). Analysis of albumin-free serum fractions showed the superior specificity of the bromocresol purple methods (tab. 3). Contrary to the observations of Pinnell \& Northam (6), we found that serum proteins other than albumin give a reaction on ACA. The lack of specificity of the bromocresol green methods is caused by a time dependent reaction with $\alpha$ - and $\beta$ globulins (1). Contrary to the finding of Webster (1) we also found a reaction with $\gamma$-globulins (tab. 3). We also observed the time dependency of the nonspecific response. The bromocresol green SMAC method (reaction time $1.5 \mathrm{~min}$ ) correlated better with the radial immunodiffusion method than the bromocresol green ACA method (reaction time 4.3 $\min )$.

Spencer \& Price (24) showed that slight differences in reagent composition can lead to large differences between the bromocresol green reactions with human and non-human serum. We made different bromocresol purple reagents for the SMAC and analysed human and bovine sera. Human serum samples gave identical values but bovine sera reacted differently. Increasing concentrations of bromocresol purple, which must be accompanied by increases in the Brij-35 concentration, showed an increasing reactivity with bovine serum. The bromocresol purple ACA ${ }^{2}$ method (250 $\mu \mathrm{mol} / 1$ bromocresol purple) gave higher values for bovine serum than the bromocresol purple SMAC method ( $80 \mu \mathrm{mal} / 1$ bromocresol purple) (tab. 6). Also, the bromocresol green methods 
reacted differently with bovine serum (tab.6). Though non-human serum is considered unsuitable for standardization (24), many bromocresol green methods make use of it. Together with the fact that most quality control sera are non-human based, this hampers the introduction of the bromocresol purple method. The most recent Technicon calibration serum is also non-human based and this manufacturer has not introduced the bromocresol purple method.

The isolation of albumin from sera yielded albumin fractions that contained traces of $\alpha$-globulins detectable by immunoelectrophoresis. It is possible that some of these traces also appeared in the dimer fractions of the HPLC analysis. The polymer fractions of the serum albumins may therefore be somewhat lower than we estimated. However, this does not influence our conclusion that freeze-drying of serum, contrary to freeze-drying of pure albumin, is not necessarily accompanied by the induction of polymers. In two freeze-dried sera, the albumin calibrator from DuPont and Versatol from General Diagnostics, we found increased polymerization.

It is not known how these sera had been treated or whether purified albumin was added or not. Our findings therefore do not support the contention of Hobbs et al. (13), that a freeze-dried serum standard should not be used, owing the induction of the polymerization of some proteins such as albumin. Differences are indeed found between the results of freeze-dried sera (tab.6), as also mentioned by Northam (9), but these cannot be ascribed merely to the polymerization.

A more severe problem is the different reactivity of the dyes with purified albumin (tab. 4). Purified albumin binds more bromocresol purple than fresh serum albumin, causing an overestimation of about $10 \%$. Binding with bromocresol green shows an opposite effect, causing an underestimation of 10$20 \%$. The isolation procedure of the albumin must be responsible for this effect; in addition to polymerization, this can cause changes in mercaptoalbumin and mixed disulphide composition (25). Purified human albumin must therefore be used with great care if it is intended as a standard for albumin determinations. Method correlation studies might not always give true results, owing the type of albumin preparation used for standardization $(15,16,17)$. Pinnell \& Northam (6) also observed a better correlation between bromocresol green and bromocresol purple methods when they calibrated with a serum standard.

\section{In conclusion}

- The bromocresol purple methods are superior to the bromocresol green methods with regard to specificity, and they correlate very well with the radial immunodiffusion method, though attention must be given to lipaemic sera.

- Different bromocresol purple methods correlate better with each other than do the bromocresol green methods.

- Freeze-dried sera can be used as standards for the serum albumin determination. Purified albumin should be used with great care.

- Non-human sera cannot be employed for calibration, they can only be used for precision control. This is a limitation in the use of bromocresol purple.

\section{Acknowledgements}

We thank the Red Cross Blood Bank of Rotterdam for supplying the donor serum. We arc gratcful to Prof. J. R. Hobbs for the gift of the IFCC serum and to Ir. W.J. Duimel for the gift of the W.H.O. serum. We thank DuPont de Nemours. The Netherlands, for the gift of test packs, Technicon Instruments (The Netherlands) for the co-operation and Mrs. H. A. Roetering and Mr. L. $P$. Struik for thcir technical assistance.

\section{References}

1. Webster, D. (1974) Clin. Chim. Acta 53, 109-115.

2. O'Donnell, N. \& Lott, J. A. (1978) Clin. Chem. 24, 10() 4$.

3. Ingwersen, S. \& Raabo, E. (1978) Clin. Chim. Acta 8\&, 545550 .

4. Gustafsson, J. E. C. (1976) Clin. Chem. 22, 616-622.

5. Louderback, A., Mealy, E. H. \& Taylor, N. A. (1968) Clin. Chem. 14, 793.

6. Pinnell, A. E. \& Northam, B. E. (1978) Clin. Chem. 24, 8086.

7. Frederichsen, P. \& Kierulf, P. (1979) Clin. Chem. 25, 1180.

8. O'Leary, N. \& Duggan, P. F. (1980) Clin. Chem. 26, 793.

9. Northam, B..E. (1981) Ann. Clin. Biochem. 18, 189-199.
10. Duggan, J. \& Duggan, P. F. (19\$2) Clin. Chem. 28, 141171408.

11. Tel, R. M., de Jong, J. \& Berends, G. T. (1979) J. Clin. Chem. Clin. Biochem. 17, 627-6331.

12. Hobbs, J. R., Harboe, N., Alper, C.. Johansson, B. G. \& Pcters, Th. (198()) J. Clin. Chem. Clin. Biochem. Is. 96-98.

13. Hobbs, J. R., Harboc, N.. Alper. C. \& Johansson, B. G. (1980) J. Clin. Chem. Clin. Biochem. 18,99-103.

14. Blaabjerg. O. \& Petersen, H. (1970) Scand. J. Clin. Lab. Invest. $39,751-757$

15. Gulyassy, P. F., Depner, T. A. d Ma, W. K. (|9SI) Clin. Chem. 27, 322-32.5. 
16. Robertson. W. S. (1981) Clin. Chem. 27, 144-146.

17. Walsh. R. L. (1983) Clin. Biochem. 16, 178-181.

18. Reimer, C. B., Smith, S. J., Hannon, W. H., Ritchie, R. F., van Es. L.. Becker, W., Markowitz, H., Gauldie, J. \& Anderson. S. G. (1978) J. Biol. Stand. 6, 133-158.

19. Travis. J.. Bowen. J., Tewksbury, D., Johnson, D. \& Pannell, R. (1976) Biochem. J. 157, 301-306.

20. Haythorn, P. \& Sheehan, M. (1979) Clin. Chem. 25, 194.

21. Blijenberg, B. G. \& Leijnse, B. (1983) J. Clin. Chem. Clin. Biochem. 21, 601-604.
22. Feldmann, U., Schneider, B., Klinkers, H. \& Haeckel, R. (1981) J. Clin. Chem. Clin. Biochem. 19, $121=137$.

23. Harff, G. A. (1983) J. Clin. Chem. Clin. Biochem. 21, 679682.

24. Spencer, K. \& Priçe, C. P. (1977) Ann. Clin. Biochem. 14, $105-115$.

25. Janatova, J. (1974) J. Med. 5, 149+216.

Drs. H. A. Assink

Dept. of Clinical Chemistry .

Wilhelmina Ziekenhuis

Zuidersingel 1

NL-9400 RA Assen 